\title{
Comparison between Parents and Teachers Assessment of Language Development for Infants: 18-35 Months
}

\author{
Yun-hee Kim, Kyunghee Jung \\ Department of Speech and Language Pathology, Graduate School of Rehabilitation and Welfare, Yongin University, Yongin, Korea
}

\author{
Correspondence: Kyunghee Jung, $\mathrm{PhD}$ \\ Department of Speech Language Rehabilitation, \\ Yongin University, 134 Yongindaehak-ro, \\ Cheoin-gu, Yongin 17092, Korea \\ Tel: +82-31-8020-2864 \\ Fax: +82-31-8020-3075 \\ E-mail: 1012jkh@hanmail.net
}

Received: April 5, 2021

Revised: May 4, 2021

Accepted: May 18, 2021

This work is based on a part of the first author's master's thesis from Yongin University.

\begin{abstract}
Objectives: The purpose of this study is to provide clinicians with clinical information about language and vocabulary development in infants by comparing the assessments of parents and teachers. Methods: A total of 128 parents and teachers of preschoolers of typical disabilities assessed the level of language development of a child. The language ability of infants was measured by SELSI and K M-B CDI. Results: The results of the study are as follows. Firstly, there was a positive correlation between parents and teachers on the SELSI total score, and the receptive and expressive language score. Additionally, a positive correlation was also observed within each age group. Secondly, there was a difference between the total scores in assessments from parents and teachers, where teachers showed higher scores in their assessments. However, there was no significant difference in both the receptive and expressive language. By observing the three different age groups, within the group of 30 to 35 months, there was a significant difference between assessments of parents and teachers in only the SELSI total score. Whereas for the other two age groups, there was no significant difference observed. Thirdly, there was a positive correlation between parents and teachers on the K M-B CDI total, expressive lexicon, and grammar score. Additionally, a strong positive correlation was also observed within each age group. Fourthly, there was no significant difference between the all area of the scores in assessments from parents and teachers. Furthermore, within each age group, there was also no significant difference observed. Conclusion: The results of this study suggest that it is necessary to consider not only the parents but also the teacher's assessment when evaluating language development for infants. And this study provides useful clinical information for early assessment and intervention in infants who show signs of delayed language development.
\end{abstract}

Keywords: Infant, Parent, Teacher, Assessment, Language development
의사소통이란 영유아가 자신의 의도와 목적을 전달하기 위해타 인에게 제스처, 발성, 언어 등의 신호와 상징을 표현하는 상호작용 행위이다(Wetherby \& Prizant, 2002). 영유아는 태어나면서부터 타인과의 교류에 적극적으로 참여하면서 전언어적 의사소통능력 을 발달시키고, 몇 년 지나지 않아 언어적 의사소통을 습득하게 된 다(Wetherby, Warren \& Reichle, 1998). 전언어적 의사소통으로 몸 짓, 눈길, 미소를 사용하기 시작하고 점차 영유아가 생활하는 사회 에서 관례적으로 정한 발화나 문어를 상징적으로 사용하면서 의 사소통이 발달해 나간다(Kim, 2014).
영유아기의 언어발달은 모의 태내에서의 듣기활동을 시작으로 출생 이후에도 통합적으로 발달해 간다. 출생 후 다양한 소리를 지 각하여 소리 나는 쪽으로 머리를 돌리는 등 소리에 민감한 반응을 보이기도 하며, 생후 3 개월 전후로는 양육자의 말소리에 반응하고, 5 개월이면 자신의 이름에 반응하게 된다. 그리고 12 개월이 되면 양 육자의 말을 듣고 다양한 몸짓이나 발성 등으로 반응한다(Joo, 2010). 16-18개월경에는 여러 낱말로 이루어진 문장을 이해하고, 문장에 나타난 의미 관계도 이해하게 되며(Kim, Kim, Yoon, \& Kim, 2003), 18-20개월경에는 두 개의 단어를 결합하고 두 개 단어를 조합한 이 
어문 표현이 시작되며(Kim, 2014), 2 세경에는 300 개 정도의 단어를 사용한다(Jang, 2004). 영유아의 전반적인 언어발달은 신생아 이후 부터 울음, 쿠잉, 옹알이 등의 비언어적인 형태로 발달하는 언어이 전기(Beaty \& Pratt, 2003) 단계를 거치면서 다양한 경험을 통해 지 속적이고 점진적으로 언어기로 나아간다. 특히 생후 18-24개월경 전후로는 어휘의 폭발적 팽창기를 거치면서 비약적으로 발달해 나 간다(Goldfield \& Reznick, 1990).

그런데 모든 영유아의 언어발달이 정상적으로 이루어지지 않는 다. 출생 직후 잘 판별되지 않는 단순언어장애 및 자폐범주성장애 아동의 경우에 3 세 미만부터 정상 아동과 다른 언어발달 특성을 나타내는 경우가 있다. 이러한 언어발달 위험군 아동에 대한 조기 평가는 발달장애 영유아의 경우 언어발달 위험요인을 조기에 발견 하고, 적절한 조기 중재를 제공함으로써 언어장애로 발전될 위험 을 감소시킬 수 있기 때문에 중재 효과에서나 발달 예후에도 더 긍 정적이다(Serna, Nielsen, Lambros, \& Forness, 2000).

조기 평가 및 조기 중재는 영유아기 언어장애에 대한 인식과 지 원 확대로 장애의 발생을 미연에 방지 및 최소화하여 장애 아동 및 가족들의 삶의 질을 향상하며 사회적 부담을 경감시키는 효과가 있다(Serna et al., 2000). 왜냐하면 발달지연 영유아의 주 양육자인 어머니는 영아의 월령별 발달에 따른 부족한 양육 정보, 역할 부담 의 과중함, 부족한 수면 시간, 지출의 증가, 자신만을 위한 시간의 감소 등 심리적인 심한 스트레스를 경험하고(Kang, 2011), 지속적 인 발달지연에 대한 불안감에 상황적 스트레스가 높다(Lee, 1994). 이러한 조기 발견의 중요성이 강조되면서 최근에는 국가 및 지방자 치 단체장의 책임하에 지역의 보건소, 병원, 의원에서 무상으로 선 별검사를 받을 수 있고 관할구역의 어린이집에서 영유아 대상으로 선별검사를 하도록 하는 '장애인복지법'과 '장애인 등에 대한 특수 교육법'이 법령으로 지정되어 있다. 국가통계포털에 따르면 2018년 연령별 보육아동 현황에서 0 세 126,793 명, 1 세 319,016 명, 2 세 397,955 명, 3세 233,274명, 4세 169,328명, 만 5세 163,314명으로 만 0-1세 영 유아들의 보육시설 이용이 전체 영유아 중에서도 $32 \%$ 로 높은 이 용률을 보인다. 보육시설 이용이 늘어남에 따라 다양한 사회적 상 호작용 기회로 언어문제점이 노출되는 가능성이 높다. 국내외 많은 연구자들은(Robins, Fein, Barton, \& Green, 2001; Wetherby, Brosnan-Maddox, Peace, \& Newton, 2008) 3세 이전 영유아 시기에 장 애를 충분히 판별할 수 있는 정도의 증상이 나타나고 선별검사를 통해 언어문제에 어려움을 갖는 영유아에게 조기에 개입을 해줌으 로써 영유아, 부모, 교사에게 도움을 줄 수 있다고 제안한다.

언어평가는 영유아 대상 직접 검사와 부모보고를 통한 간접 평 가 방식으로 구분된다. 영아의 행동관찰을 직접 검사로 Wetherby
와 Prizant (2002)에 의해 개발된 Communication and Symbolic Behavior Scale-Development Profile (CSBS DP)는 선별검사인 CSBS DP 영유아 점검표(ITC)와 진단검사인 행동샘플검사(behavior sample), 양육자보고검사(parent questionnaire)로 구성되 어 있다. 이 중 행동샘플검사는 검사자가 관찰하여 영유아의 행동 을 직접 평가하며 양육자보고검사를 통해서 얻어진 결과와 종합하 여 영유아의 의사소통 행동발달을 평가한다. 그런데 3 세 이하 영유 아의 언어발달 과정에서의 개인차 매우 다양하다. 정상발달 아동 16 개월 영유아들의 표현어휘 범위가 9 개 미만부터 198 개를 넘기도 하고, 20 개월 영유아들의 표현어휘 범위가 41 개 미만부터 405 개가 넘기도 하고 있으며(Fenson et, al., 1993), 낮선 환경에서 낮선 사람 들과 상호작용하기를 꺼리고(Thal, O'Hanlon, Clemmons, \& Fralin, 1999) 평가 시간이 제한되거나 의사소통 의도가 없는(noncommunicative) 영유아들은 직접 관찰이 어려워(Tomblin, Shonrock, \& Hardy, 1989) 많은 임상가들이 직접 검사를 통해 장애를 판별하 기 어려운 경험을 자주 하게 된다. 이처럼 조기 선별을 위해 영유아 대상으로 직접 검사를 적용하는데 제한이 있기 때문에 부모보고 를 통한 간접 검사 방법을 언어평가를 위한 대안적 방법으로 널리 사용하고 있다. Thal 등(1999)에 의하면 부모보고를 통한 평가 방 법은 사용이 용이하며 다양한 환경에서 관찰된 자녀의 행동을 반 영하여 대표성 있는 언어자료를 제공할 수 있다고 했다. 또한 경제 적인 비용 및 시간이 절약되며, 심화검사를 위한 치료사의 적절한 평가 방법을 선택하는데 지침이 될 수 있다고 하였다. 반면 Merydith, Prout와 Blaha (2003)는 부모는 실제 영유아의 행동에 대한 평가보다는 사회적으로 기대되는 방식으로 응답할 경향이 있기 때 문에 객관적이고 정확하지 않을 수 있음을 지적하며 제한점이 있 음을 보고했다. 부모는 초기의 언어학적인 형태를 인식하는 능력 부족에서 비롯된 편견 등으로 인해 자녀들의 언어발달 보고가 불 분명할 수 있다(Dale, 1991; Dale, Bates, Reznick, \& Morisset, 1989) 는 문제점이 있다.

반면 많은 영유아 언어평가에 있어 부모 외의 성인 즉 교사의 영 향력이 무시할 수 없는 중요한 요인으로 주목받고 있다. 교사는 영 유아와 일상생활에서 자연스럽게 상호작용을 하면서 영유아의 전 반적인 발달 상황에 대해 관찰하고 살피면서 특정 영역에서 이상 징후(red flag)가 발견되면 아동발달의 지식에 근거로 판단하여 부 모에게 고지해야 하는 의무와 책임이 있다. 교사는 또래 유아들의 정보를 통해 상대적인 비교가 가능하고 비교적 객관적인 평가가 가 능하다(Park \& Lee, 2001). 교사들은 다양한 영유아들과의 상호작 용을 통해 영유아 행동 양상에 대한 비교 평가가 가능하며, 교육기 관내에서 또래와의 상호작용 맥락에서 영유아의 사회적 의사소통 
능력을 관찰할 기회가 더 많다(Lee \& Choi, 2012). 그런데 몇몇 연구 자들은 교사들의 평가가 부모에 비해 행동문제를 세부적으로 판 단하는 정확성이 떨어지고 있다고 지적하기도 한다(Green, Beck, Forehand, \& Vosk, 1980; as cited in Song \& Kim, 2002). 교사들이 적응에 어려움을 느끼는 영유아를 찾아낼 수 있으나 문제의 유형 을 감별해내는 면에서는 부모보다는 정확하지 못하다는 것이다.

그러므로 부모, 교사의 평가를 한쪽에 의존하기보다는 부모와 교사의 평가를 함께 비교함으로써 좀 더 다각적이고 정확하게 영 유아의 언어발달 특성을 종합적으로 관찰할 필요가 있다(Campbell, 2006). 같은 영유아의 언어능력을 평가하는 데 있어 부모와 교 사의 평가 척도가 일치하는지, 만약 불일치하다면 어떤 부분에서 차이가 나는지를 파악함으로써 향후 중재 계획을 세우는데 유용 한 정보를 제공해 줄수 있다(Kim, Ahn, \& Kim, 2012). 그런데 선행 연구들은 주로 아동기의 정서 및 행동문제를 중심으로 부모와 교 사의 평가 척도를 비교한 경우가 많다(Dickson, Suhrheinrich, Rieth, \& Stahmer, 2018; Efstratopoulou, Janssen, \& Simons, 2012; Kim et al., 2012; Lee \& Choi, 2012; Lee, Lee, \& Kim, 2013; Ruchkin, Koposov, Vermeiren, \& Schwab-Stone, 2011). 선행연구들 중 에는 아동행동평가척도 상에서 부모와 교사 보고 간의 차이가 있 다는 연구가 있는데, 특히 아동이 경험하는 문제의 특성에 따라 평 정의 일치도에 차이가 있을 수 있다고 하였다. 교사는 행동문제에 서 부모보다 더 민감하게 반응할 수 있는 반면, 부모는 교사보다 불 안이나 우울증과 같은 문제에 더 민감하게 반응할 수 있다(Efstratopoulou et al., 2012). 반면, 학령기 일반 아동을 대상으로 아동의 문제행동에 대해 평가하는 부모용 아동행동평가척도(Child Behavior Checklist, $\mathrm{CBCL}$ )와 교사용 아동행동평가척도(Teacher's Report From, TRF) 간의 평정을 비교한 연구에서 부모와 교사 평 가 간에는 유의미한 상관이 있음을 보고했다(Efstratopoulou et al., 2012). 교사가 학생들을 일상적으로 관찰하며 규범적인 행동과 문 제의 증상 범위에 대하여 잘 보고 할 수 있고, 학생들의 내면이나 학 업 및 사회적 문제들을 부모보다 더 잘 파악할 수 있기 때문에 교사 가 양쪽 영역 모두에서 부모보다 객관적으로 잘 파악할 수 있다는 상반된 연구 결과도 보고되었다(Ruchkin et al., 2011).

하지만 아동의 언어발달 평가에서 부모와 교사 간 평가 일치도 를 조사한 국내 연구는 모두 학교를 중심으로 지역사회 아동을 대 상으로 한 경우가 다수이며(Park, Choi, \& Jeong, 2010), 언어 병리 학에서는 부모와 교사와의 보고의 관계를 보고한 선행연구는 매 우 부족한 실정이다. 최근 장애 유아의 언어능력에 대한 부모, 교사, 언어재활사의 인식 비교(Shin \& Ahn, 2018)를 통해 수용언어와 표 현언어에서 차이를 살펴본 연구결과에서는 부모, 교사, 언어재활사
간의 인식의 차이가 나타나지 않았다고 보고했다. 이는 세 집단 모 두 아동에 대한 유용한 정보를 제공할 수 있음을 시사해 주는 결과 이다. 또한 Pua, Lee와 Rickard Liow (2017)는 부모와 교사의 학령 전기 이중언어아동의 수용 및 표현언어장애에 대한 선별검사 결과 가 일치하였음을 보고하였다. 하지만 같은 아동을 대상으로 부모 와 교사가 평가한 결과가 일치하는지 여부와 관련된 연구는 부족 한 실정이다. 자폐범주성장애 아동의 적응 기능과 자폐적 증상에 대한 부모와 교사의 평가 결과가 일치하는지 살펴본 연구가 있으나 언어능력에 대한 연구는 드문 실정이다(Dickson, et al., 2018). Jeff 와 Donna (1995)는 학령전기 발달장애 아동을 대상으로 수용 및 표현언어능력에 대한 부모와 교사의 평가를 비교한 연구결과를 보 고하였다. 이 연구에서 수용언어능력은 두 집단 간 차이가 있었으 나 표현언어능력은 차이가 없었다고 보고한 바 있다. 또 청각장애 아동을 대상으로 의사소통능력을 평가한 후 부모와 교사간 차이 가 유의하지 않았다고 보고한 연구가 있다(Knoors, Meuleman, \& Klatter-Folmer, 2003). 하지만 국내에서는 언어능력에 대한 두 집 단의 평가 결과 일치 여부에 대한 연구는 전무한 상황이다.

부모 보고와 교사의 보고에서 서로 견해에 대한 비교는 임상에 서 객관적인 정보에 의한 임상 진단을 내리는데 필요하며 조기 선별 과 향후 치료계획을 세우는데 유용하게 사용될 수 있다. 교사 보고 가 부모 보고를 대체할 수 있는지 알아보는 것도 중요하다. 그러므 로 본 연구는 3세 이전의 영유아를 양육하는 부모와 보육하는 교 사의 보고 결과를 비교함으로써 두 집단의 평가 결과 간의 상관이 유의한지, 평가 결과의 차이가 있는지 등에 대해 알아보고자 한다.

\section{연구방법}

\section{연구대상}

본 연구는 충남에 거주하는 18-23개월 21명, 24-29개월 21명, 30-35개월 22명을 포함한 영유아 64명의 주 양육자와, 해당 영유아 를 담임한 보육교사각 64 명, 총 128 명을 대상으로 하였다.

\section{영유아 대상자 선정 기준}

본 연구에 참여한 영유아는 소아과에서 실시한 영유아건강검진 에서 한국영유아발달검사 실시 결과 ‘정상'으로 진단되었다고 부모 에 의해 보고된 영유아로 부모 및 교사의 보고를 통해 정서 · 신체 · 인지를 포함한 전반적인 발달에 문제가 없는 영유아로 선정하였다.

\section{부모와 교사 참가자 선정 기준 및 특성}

본 연구 대상자는 일반 영유아의 부모와 해당 아동의 보육교사 
Table 1. Characters of infant participants

\begin{tabular}{lc}
\hline Group & $\mathrm{N}(\%)$ \\
\hline Sex & \\
Male & $33(51.6)$ \\
Female & $31(48.4)$ \\
Age & \\
$18-23 \mathrm{~m}$ & $21(32.8)$ \\
$24-29 \mathrm{~m}$ & $21(32.8)$ \\
$39-35 \mathrm{~m}$ & $22(34.4)$ \\
Period of daycare center & \\
6-12 m & $34(53.1)$ \\
$13-24 \mathrm{~m}$ & $25(39.1)$ \\
$25 \mathrm{~m}<$ & $5(7.8)$ \\
Total & $64(100)$ \\
\hline
\end{tabular}

이다. 부모는 일주일에 4 일 이상 자녀를 양육하고, 해당 아동의 담 임교사는 6개월 이상 매일 6시간 이상 주 4일 이상 아동을 보육하 며 민간어린이집에서 근무하는 보육교사로 선정하였다. 이와 같은 기준으로 선정된 영유아의 정보는 Table 1에 제시하였다.

본 연구에 참여한 64 명 영유아의 주 양육자 및 담임 보육교사의 특성은 다음과 같다. 주 양육자의 경우 성별은 남 4 명 $(6.3 \%)$, 여 60 명(93.8\%), 연령대는 20대 3명(4.7\%), 30대 55명(85.9\%), 40대 6명 (9.45), 최종학력은 고졸 7명(10.9\%), 전문대졸 23명(35.9\%), 대졸 34 명 (53.1\%), 직업은 주부 35명(54.7\%), 서비스직 3명(4.7\%), 사무관리직 10 명(15.6\%), 전문직 10 명(15.6\%), 생산기증직 4명(6.3\%), 기타 2명 (3.1\%)이었다. 보육교사의 경우 성별은 모두 여성이었고, 연령대는 30 대 8명(17.4\%), 40 대 35명(76.1\%), 50대 3명(6.5\%)이었으며, 최종 학력은 전문대졸 22 명(47.8\%), 대졸 9명(19.6\%), 기타 15 명(32.6\%), 교직경력은 3년미만 3명(6.5\%), 3년 이상 43명(93.5\%)이었다.

\section{검사도구}

본 연구의 대상자인 $18-35$ 개월 영유아의 전반적인 언어발달을 확인하기 위하여 SELSI (Kim, Kim, Yoon, \& Kim, 2003)를, 표현어 휘 발달을 보기 위하여 K M-B CDI (Pae \& Kwak, 2002)를 평가 도 구로 선정하였다.

\section{영유아 언어발달 검사(SELSI)}

언어능력을 측정하기 위해 영유아 언어발달 검사(Sequenced Language Scale for Infants, SELSI; Kim et al., 2003)를 실시하였다. 본 검사는 생후 5-36개월 사이의 정상발달 영유아 및 언어발달지 체나 장애를 나타낼 가능성이 있는 유아 및 아동들의 수용언어와 표현언어능력을 평가하는 데 사용할 수 있다, 화용, 의미, 음운, 문
법 등 영유아의 언어발달에 대한 전반적인 언어발달 능력에 대한 정보, 생활연령과 비교하여 대상 영유아의 상대적인 언어발달 수 준을 알수 있다.

\section{한국판 맥아더-베이츠 의사소통검사(K M-B CDI)}

언어능력을 측정하기 위해 K M-B CDI (MacArthur-Bates Communicative Development Inventory-Korean, K M-B CDI; Pae \& Kwak, 2002)를 실시하였다. 본 검사는 아동의 어머니(주 양육자)가 아동이 산출하는 낱말과 이해하는 낱말을 표시하여 아동의 이해 및 표현어휘를 모두 평가할 수 있는 도구이며 제츠처와 놀이 및 문 법 수준을 평가할 수 있다. 검사도구의 구성은 표현 24 문항, 이해 24 문항, 문법과 문장 4 문항으로 이루어져 있다.

\section{연구절차 및 자료분석}

\section{자료 수집}

본 연구의 조사는 2020 년 1 월부터 4 월까지 약 4 개월 동안 진행되 었다. 연구 대상 표집은 충남육아종합지원센터 홈페이지에서 0 세 반부터 만 2 세반 아동을 대상으로 하는 어린이집 리스트를 참고하 였다. 위의 조건에 해당하는 10 개 어린이집을 선정하여 어린이집에 언어발달평가 및 의사소통발달 검사에 대한 협조 요청 공문을 보냈 다. 협조 공문에 대해 기관 참여에 동의한 어린이집은 8 개 기관이었 다. 기관 참여 의사를 회신 받은 직후 연구자가 아동 평가 실시에 동 의한 어린이집에 직접 방문하여 진단 목적과 검사지 기록 방법에 대 해 교사 교육을 실시하였다. 매뉴얼에 제시된 SELSI 평가 절차는 수 용언어 영역부터 시작하고, 시작 문항 선정 방법은 영유아의 생활연 령에 해당하는 연령 단계에서 두 단계 낮은 연령 단계의 첫 번째 문 항부터 시작한다. 그러나 부모를 직접 만나 해당 검사 절차를 직접 설명하는데 현실적으로 제한이 있어 부모가 쉽게 검사 절차를 이해 할 수 있도록 절차를 수정하여 시작하는 문항을 1 번부터 평가하도 록 안내하여 평가를 실시하도록 하였으며 교사에게도 같은 방법으 로 평가할 수 있도록 안내하였다. 교육내용은 SELSI를 수정하여 문 항 1 번부터 시작하며 영유아가 수행할 수 있는 문항에는 “예”, 수행 할 수 없는 문항에는 “아니오”라고 표시하도록 하였다. K M-B CDI 는 첫 문항부터 마지막 문항까지 표시하고, 검사지 상단에 기재된 방법에 따라 모든 문항에 대해 평가를 수행하도록 하였다.

어린이집에서 연구목적과 평가 방법에 관한 안내문과 검사지를 가정으로 보냈고 가정에서는 안내문을 숙지 후 평가를 하고 검사지 를 어린이집으로 회수하도록 하였다. 회수에 걸린 시간은 배부 후 1 주일 정도 소요되었고 연구자가 직접 찾아가 부모와 교사의 검사지 를 함께 회수하였다. 검사지를 부모에게 100 부, 교사에게 100 부로 
Yun-hee Kim, et al. • Parents and Teachers Assessment of Language Development

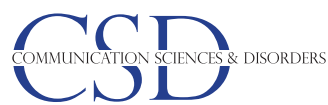

총 200 부를 배포하였고 각각 보고자 별 76 부를 수거하였다. 이 중 한쪽 보고만 있는 12 부를 제외한 64 부로 통계처리하였다.

\section{자료 처리}

SELSI는 1번 문항부터 마지막 문항까지 각 문항에 대해 “예”라 고 기록한 경우 1 점, "아니오”라고 기록한 경우 0점으로 평가하여 총 점수를 계산하였다. $\mathrm{K} \mathrm{M-B} \mathrm{CDI는} \mathrm{낱말} \mathrm{영역에서} 1$ 번부터 마지 막 문항까지 표시한 수만큼 총 점수를 계산하고 제스처 및 놀이, 문 법과 문장은 “종종”이라고 기록한 경우 2점, “가끔”이라고 기록한 경우 1점, “안 함”이라고 기록한 경우는 0점으로 평가하였다. 각 영 역별 점수의 범위는 641 개의 낱말, 5 개의 문법 사용 정도, 32 쌍의 문장으로 구성된 문법항목을 포함한 총 점수를 계산하였다. 연구 결과에 대한 통계처리는 전반적인 언어발달과 어휘능력에 대한 부 모와 교사가 평가한 점수의 상관관계를 알아보기 위해 피어슨 적 률 상관분석을 통해 자료를 처리하였다. 그리고 전반적인 언어발달 과 어휘능력에 대한 부모와 교사의 평가에 차이가 있는지 알아보 기 위해 $t$-검정을 실시하였다. 모든 자료는 SPSS 24.0 을 사용하여 분석하였다

\section{연구결과}

\section{영유아들의 언어능력 평가에 대한 부모와 교사 보고}

영유아의 전반적 언어능력에 대한 부모와 교사 평가 간 상관관계

SELSI에서 부모와 교사의 평가를 통해 확인된 아동의 전반적 언 어능력을 영역별로 살펴보면, 전체점수 및 수용, 표현영역 간의 상 관 범위는 $r=.993-998$ 으로 나타나 부모와 교사 평가 간 매우 높은 상관관계가 있는 것으로 나타났다. 부모와 교사는 전체점수 간에 상관이 $r=.998$ 로 매우 높은 상관관계를 보였다. 수용과 표현언어 하위영역별로 살펴보면 수용언어에서 부모와 교사 간 평가 점수의 관련성은 $r=.993$, 표현언어에서 부모와 교사 간 평가 점수의 관련 성은 $r=.998$ 으로 나타나 매우 높은 상관관계를 보였다.

연령대별 SELSI 평가에서 부모와 교사 평가 점수 간 상관관계를 분석한 결과 세 연령대 모두, 모든 하위 영역에서 .98 이상의 매우 높

Table 2. Correlation between parent and teacher scores by age group for SELSI

\begin{tabular}{lllcc}
\hline SELSI & $\mathrm{N}$ & Total & Receptive & Expressive \\
\hline $18-23 \mathrm{~m}$ & 21 & $.998^{* *}$ & $.991^{* *}$ & $.998^{* *}$ \\
$24-29 \mathrm{~m}$ & 21 & $.995^{* *}$ & $.981^{* *}$ & $.998^{* *}$ \\
$30-35 \mathrm{~m}$ & 22 & $.998^{* *}$ & $.996^{* *}$ & $.996^{* *}$ \\
\hline
\end{tabular}

SESLI = Sequenced Language Scale for Infants (Kim et al., 2003). ${ }^{*} p<.05,{ }^{* *} p<.01$.
은 상관관계를 보이는 것으로 나타났으며, 구체적 상관계수는 Table 2에 제시되어 있다.

영유아의 전반적인 언어능력에 대한 부모-교사 평가 간 차이

SELSI에서 부모와 교사 평가 전체 및 수용, 표현영역 간의 차이 가 있는지 알아보기 위해 실시한 $t$-검정 결과 SELSI 전반적 언어능 력에 대한 부모 평가 점수에 비해 교사 평가 점수가 높게 나타났으 며 통계적으로 이 차이가 유의하였다 $(t=-2.216, p<.05)$. 반면 SELSI 수용 $(t=-1.196, p>.05)$, 표현 $(t=-1.915, p>.05)$ 의 하위영역에서 는 모두 부모와 교사 평가 간 차이가 없는 것으로 나타났다.

또한 연령대별 SELSI에서 부모와 교사 평가 전체 및 수용, 표현영 역 간의 차이가 있는지 알아보기 위한 $t$-검정을 실시한 결과, 18-23 개월, 24-29개월에서든 모든 영역에서 두 집단 간 평가 점수 차이가 유의하지 않았으나, 30-35개월 아동의 전체 평가 점수에서만 부모 와 교사 간 차이가 유의한 것으로 나타났으며, 그 결과는 Table 3에 제시하였다.

\section{영유아들의 어휘능력에 대한 부모-교사 보고}

$\mathrm{KM}$-B CDI의 전체, 표현어휘, 문법 점수에서의 부모-교사의 보고 간의 상관관계

$\mathrm{K} \mathrm{M}-\mathrm{B}$ CDI에서 부모와 교사가 평가한 전체 총점, 표현어휘 및

Table 3. T-test results for parent and teacher scores by age group for SELSI

\begin{tabular}{|c|c|c|c|c|c|c|}
\hline Age & SELSI & Group & $\mathrm{N}$ & M & SD & $t$ \\
\hline \multirow[t]{6}{*}{$18-23 \mathrm{~m}$} & \multirow[t]{2}{*}{ Total } & Parents & 21 & 75.76 & 15.90 & \multirow[t]{2}{*}{-.810} \\
\hline & & Teachers & 21 & 75.95 & 15.76 & \\
\hline & \multirow[t]{2}{*}{$\mathrm{R}$} & Parents & 21 & 41.76 & 8.41 & \multirow[t]{2}{*}{-.384} \\
\hline & & Teachers & 21 & 41.86 & 8.41 & \\
\hline & \multirow[t]{2}{*}{$E$} & Parents & 21 & 34.00 & 8.31 & \multirow[t]{2}{*}{-.810} \\
\hline & & Teachers & 21 & 34.10 & 8.26 & \\
\hline \multirow[t]{6}{*}{$24-29 \mathrm{~m}$} & \multirow[t]{2}{*}{ Total } & Parents & 21 & 93.14 & 12.53 & \multirow[t]{2}{*}{-1.101} \\
\hline & & Teachers & 21 & 93.43 & 12.51 & \\
\hline & \multirow[t]{2}{*}{ R } & Parents & 21 & 49.24 & 5.61 & \multirow[t]{2}{*}{-.400} \\
\hline & & Teachers & 21 & 49.33 & 5.46 & \\
\hline & \multirow[t]{2}{*}{$E$} & Parents & 21 & 43.90 & 8.51 & \multirow[t]{2}{*}{-1.706} \\
\hline & & Teachers & 21 & 44.10 & 8.39 & \\
\hline \multirow[t]{6}{*}{$30-35 \mathrm{~m}$} & \multirow[t]{2}{*}{ Totall } & Parents & 22 & 101.64 & 12.35 & \multirow[t]{2}{*}{$-2.160^{*}$} \\
\hline & & Teachers & 22 & 102.00 & 12.12 & \\
\hline & \multirow[t]{2}{*}{$\mathrm{R}$} & Parents & 22 & 52.82 & 5.65 & \multirow[t]{2}{*}{-2.017} \\
\hline & & Teachers & 22 & 53.05 & 5.66 & \\
\hline & \multirow[t]{2}{*}{$E$} & Parents & 22 & 48.91 & 7.56 & \multirow[t]{2}{*}{-.901} \\
\hline & & Teachers & 22 & 49.05 & 7.35 & \\
\hline
\end{tabular}

$\mathrm{R}=$ Receptive language; $\mathrm{E}=$ Expressive language; $\mathrm{SESLI}=$ Sequenced Language Scale for Infants (Kim et al., 2003).

${ }^{*} p<.05$. 
Table 4. Correlation between parent and teacher scores by age group for $\mathrm{K}$ M-B CDI

\begin{tabular}{llccc}
\hline K M-B CDI & N & Total & Vocabulary & Grammar \\
\hline $18-23 \mathrm{~m}$ & 21 & $.958^{* *}$ & $.943^{* *}$ & $.977^{* *}$ \\
$24-29 \mathrm{~m}$ & 21 & $.993^{* *}$ & $.979^{* *}$ & $.999^{* *}$ \\
$30-35 \mathrm{~m}$ & 22 & $.853^{* *}$ & $.866^{* *}$ & $.954^{* *}$ \\
\hline
\end{tabular}

K M-B CDI=Korean version MacArthur-Bates Communicative Development Inventories (Pae \& Kwak, 2011). ${ }^{*} p<.05,{ }^{* *} p<.01$.

문법 점수간 상관 계수의 범위는 $r=.796-967$ 로 나타나 각 변수 간 의 상관이 높은 것으로 나타났다. 부모와 교사는 전체 점수 $(r=.967)$ 에서 매우 높은 상관관계를 보였다. 또한 표현어휘 $(r=.953)$, 문법 $(r=.953)$ 의 하위 항목에서도 부모와 교사 평가 간 매우 높은 상관 관계를 나타냈다.

연령대별로 동일한 영유아에 대하여 부모와 교사가 각각 평가한 $\mathrm{K}$ M-B CDI 평가 점수에 대한 상관관계를 분석한 결과 Table 4에 제시된 바와 같이 18-23개월( $r=.943-.977), 24-29$ 개월 $(r=.979$ .999) 두 연령 집단의 경우 .94이상의 매우 높은 상관관계를 보였고, $30-35$ 개월의 경우 $r=.853-.954$ 로 다른 연령 단계에 비해서는 다소 낮은 편이나 역시 매우 높은 상관관계를 보였다.

\section{$\mathrm{KM}-\mathrm{B} \mathrm{CDI}$ 평가에서의 부모-교사의 평가 차이}

$\mathrm{K} \mathrm{M}-\mathrm{B}$ CDI에서 부모와 교사가 평가한 전체 총점, 표현어휘 및 문법 점수간 점수차이가 있는지 알아보기 위한 $t$-검정 결과에서는 $\mathrm{K} \mathrm{M}-\mathrm{B} \mathrm{CDI}$ 전체 점수 $(t=-496)$ 간에 서로 차이가 없는 것으로 나 타났다. K M-B CDI 표현어휘 $(t=-1.067)$, 문법 $(t=-1.429)$ 영역 각각 부모와 교사간 평가에 차이가 없는 것으로 나타났다(Table 5).

\section{논의 및 결론}

본 연구는 3세 이전의 영유아를 양육하는 부모와 보육하는 교사 의 보고를 통해 확인된 영유아의 어휘와 언어발달을 비교함으로써 부모 및 교사 보고의 관계에 대한 정보를 제공하기 위한 목적으로 수행되었다.

연구결과는 첫째, 본 연구에서 동일한 영유아에 대하여 부모와 교사가 각각 평가한 SELSI 평가 점수에 대해 상관관계를 분석한 결 과 서로 높은 상관관계를 나타냈다. 연령대에 따라 부모와 교사가 각각 평가한 SELSI 평가 점수에 대해 전체, 수용, 표현영역에서 서 로 높은 상관관계를 나타냈다. 또한 동일한 영유아에 대하여 부모 와 교사가 각각 평가한 SELSI 평가 점수에 대해 18-29개월 시기에 는 두 보고자 간 차이가 나지 않았으나 30-35개월에서는 전반적으
Table 5. T-test results for parent and teacher scores by age group for K M-B CDI

\begin{tabular}{|c|c|c|c|c|c|c|}
\hline Age & K M-B CDI & Group & $\mathrm{N}$ & M & SD & $t$ \\
\hline \multirow[t]{6}{*}{$18-23 \mathrm{~m}$} & Total & Parents & 21 & 680.97 & 393.49 & -.307 \\
\hline & & Teachers & 21 & 685.34 & 395.73 & \\
\hline & Vocabulary & Parents & 21 & 266.03 & 217.41 & -.597 \\
\hline & & Teachers & 21 & 271.50 & 218.31 & \\
\hline & Grammar & Parents & 21 & 24.23 & 25.57 & -.725 \\
\hline & & Teachers & 21 & 24.75 & 26.44 & \\
\hline \multirow[t]{6}{*}{$24-29 \mathrm{~m}$} & Total & Parents & 21 & 761.29 & 267.62 & -.543 \\
\hline & & Teachers & 21 & 762.48 & 268.49 & \\
\hline & Vocabulary & Parents & 21 & 289.71 & 158.16 & -.184 \\
\hline & & Teachers & 21 & 291.00 & 160.29 & \\
\hline & Grammar & Parents & 21 & 24.00 & 19.61 & -.237 \\
\hline & & Teachers & 21 & 24.05 & 19.42 & \\
\hline \multirow[t]{6}{*}{ 30-35 m } & Total & Parents & 22 & 980.50 & 322.52 & -.452 \\
\hline & & Teachers & 22 & 997.45 & 325.11 & \\
\hline & Vocabulary & Parents & 22 & 428.00 & 218.16 & -1.016 \\
\hline & & Teachers & 22 & 452.00 & 209.48 & \\
\hline & Grammar & Parents & 22 & 41.00 & 28.66 & -1.417 \\
\hline & & Teachers & 22 & 49.05 & 7.35 & \\
\hline
\end{tabular}

${ }^{*} p<.05$.

로 부모보다 교사 평가 점수가 더 높았고, 특히 전체 점수에서 통계 적으로 유의한 차이가 나타났다. 본 연구결과 부모와 교사 간의 평 가가 상관이 유의하였고, 30-35개월 아동의 SELSI 전체 점수를 제 외한 모든 영역에서 두 집단 간 차이가 없었는데 이는 한국어판 강 점난점설문지(Korean version of Strengths and Difficulties Questionnaire)와 한국어판 아동행동평가척도를 이용하여 아동의 정신 병리에 대한 부모-교사 평가의 일치도를 알아본 연구에서 전반적 으로 정보 제공자의 보고가 서로 일치하는 경향이 있음을 보고하 였다(Kim et al., 2012). 본 연구결과는 Kim 등(2012)이 아동의 정신 병리에 대한 부모-교사 평가가 서로 일치한다고 보고한 연구를 지지 해 주고 있다. 그런데 본 연구에서도 18-29개월에서는 부모와 교사 간 평가 차이가 없게 나타나 위 연구를 지지해 주고 있으나 30-35개 월은 전체 점수에서 두 집단 평가 간 차이가 있었다. 18-29개월은 30-35개월 연령대보다 몸짓을 동반한 언어를 사용하여 상호작용 을 하는 시기이다. Lee와 Lee (2016) 연구에서는 19-24개월부터 언 어로 주된 의사소통 수단을 사용하나 몸짓 동반 언어를 언어에 비 해 유의하게 많이 사용하고 24-30개월에는 언어와 몸짓 동반 언어 가 거의 비슷하게 사용하며 18-29개월 사이 영유아의 주된 의사소 통 수단으로 언어와 함께 몸짓이 활발히 사용된다고 보고하였다. 따라서 이 시기는 주로 성인과 아동 간의 상호작용이 중심이며, 부 모와 교사 모두 각각 일상생활과 관련된 유사한 상황에서 상호작 
용함으로써 아동의 의도를 이해하고 반응하는 상황이 크게 다르 지 않을 수 있다. 더욱이 본 연구에 참여한 18-29개월 사이의 영유 아들은 보육시설을 6 개월 이상 규칙적이고 정기적으로 이용한 영 유아인 만큼 보육교사와의 상호작용이 부모만큼 익숙하게 느껴질 수 있기 때문에 언어와 언어로 표현하지 못한 의도를 다양한 의사 소통 몸짓을 사용하여 상호작용했을 수 있다.

반면 30개월 이상에서 차이가 난 것은 교사는 부모보다 여러 유 아들과 상호작용할 기회도 많고, 또래 유아들 간의 상호작용 상황 을 관찰할 기회도 더 많기 때문에 유아의 다양한 언어표현 기술을 자주 관찰할 수 있으며, 또래의 평균적인 기준으로 언어능력에 대 한 비교도 가능하기 때문에 교사가 부모에 비해 이 시기 아동의 다 양한 언어행동을 관찰할 기회가 많을 수 있다(Firmin, Proemmel, \& Hwang, 2005). 이 시기 교사의 유아 평가의 중요성에 대해 많은 연구자들에 의해서 반복해서 확인되고 있다. 특히 부모와 교사 간 평가 차이가 30 개월 이상의 연령대에서 차이가 나타났다는 것은 이 시기 이후 유아들의 언어능력 발달이 급속히 이루어지고 또래 상호작용이 이전 연령대에 비해 활발히 이루어지는 시기이기 때문 에 교사가 유아의 또래 관계를 관찰할 기회가 많았기 때문에 나타 날 가능성이 있다. Park과 Lee (2001)의 연구에서는 교사가 또래의 여러 유아에 대한 정보를 통해 상대적인 비교가 가능하고 비교적 객관적인 평가가 가능하다고 보고하였는데 이는 교사가 유아의 다 양한 언어능력을 관찰할 가능성이 더 많음을 의미하는 것이다. Lee 와 Choi (2012)는 다문화 가정 3-5세의 행동문제에 대한 부모와 교 사의 평가 차이를 연구했는데 연구결과 나이가 높을수록 부모와 교사의 평가 점수 간 차이가 더 컸다고 보고하였는데 이는 아이가 연령이 높아질수록 성인뿐 아니라 또래 간의 의사소통을 관찰할 기회를 교사가 더 많이 경험하게 되기 때문이라고 해석해볼 수 있 다. 본 연구결과에서도 30 개월 이후 아동의 교사가 부모에 비해 영 유아의 언어능력을 더 높게 평가한 것은 영유아가 다양한 언어 기 술을 사용하는 것을 관찰할 기회가 더 많았기 때문이었다고 해석 할 수 있으며 이는 위의 연구를 지지해 주는 결과이다. 특히 SELSI 검사 항목 중 30 개월 이후 상대적 크기나 위치, 비교, 색에 대한 인 지, 경험한 사건 말하기 등 교육 상황에서 관찰할 기회가 많은 항목 들로 구성되어 있는 점을 고려해볼 때 영유아기 후기 이후 교사들 의 언어 행동 관찰 결과를 평가나 중재 과정에서 고려할 필요가 있 을 것이다.

둘째, 본 연구에서 동일한 영유아에 대하여 부모와 교사가 각각 평가한 K M-B CDI 평가에 대한 상관관계가 매우 높게 나타났다. 연 령대에 따라 부모와 교사가 각각 평가한 $\mathrm{KM}$ M CDI 평가에 대해 전 체, 표현어휘, 문법 영역에서 모두 매우 높은 상관관계를 나타냈다.
동일한 영유아에 대하여 부모와 교사가 각각 평가한 $\mathrm{KM}-\mathrm{B} \mathrm{CDI}$ 평 가에서는 두 보고자 간 차이가 없는 것으로 나타났다. 이는 세 연령 대별로 두 보고자간차이를 검증한 결과에서도 다르지 않았다.

여성가족부의 보육시설에 대한 교육지침에 따르면 보육시설은 영아 보육 과정을 교육적 경험으로 일상생활 활동이 계획되고 실 천 가능해야 한다고 명시되어 있다(Ministry of gender equality and family, 2007). 또한 영유아 시기 어휘발달 특징을 연구한 Jang (2004) 연구에서 초기 표현어휘의 보통 명사는 $27 \%$ 로 사람을 지칭 하는 어휘를 포함한 명사류가 반 이상 차지하였고 명사류와 일상 생활에 관련된 어휘들이 전체 표현어휘의 $90 \%$ 정도 차지하였다. Choi (2000) 연구에서 18-29개월 영유아들이 276개의 낱말을 평균 적으로 표현 가능하며 이 시기에 습득하는 명사에는 사람, 음식, 신 체 부위, 옷, 동물, 가정 등의 일상적인 어휘들이다(Clark, 1973; Hoff, 2001). 이러한 점을 고려해보면 이 시기 영유아는 영아 보육 과정으 로 일상생활 활동이 중심이 된 보육환경에서 일상생활과 관련된 어휘를 사용하면서 교사 및 또래와 상호작용할 가능성이 높다. 따 라서 가정과 보육시설 등의 모든 상황에서 영유아가 부모나 교사와 상호작용하면서 사용하는 어휘는 일상어휘 중심의 유사한 유형일 가능성이 있다. 따라서 부모와 교사가 관찰할 수 있는 어휘 유형이 크게 다르지 않았을 것이다. 따라서 본 연구의 18-35개월의 대상자 들은 가정에서나 보육시설에서나 크게 다르지 않은 일상생활 어휘 로 상호작용하였기 때문에 교사가 부모와 비슷하게 아동이 사용하 는 어휘능력을 객관적으로 평가할 수 있었을 것이다. Kim과 Kim (2006)은 영유아에게 편안한 존재인 부모와 교사가 일상생활에서 유아의 행동을 관찰하고 평가하는 방법을 통해 자연스럽게 관찰 및 행동 수집이 가능하며, 영유아의 협조 없이도 평가할 수 있는 장 점이 있고, 교사는 우울 및 불안을 보고하는 아동들의 내재화 문제 와사회성 및 학업 수행 문제에 대해서 교사가 부모만큼 잘 파악하 고 있다고 보고하였는데(Mesman \& Koot, 2000), 이는 교사 역시 부모와 유사하게 아동의 어휘능력을 평가할 수 있기 때문에 아동 의 어휘평가 시 부모뿐 아니라 교사의 보고 역시 유의하게 아동발 달에 대한 정보를 제공해 줄 수 있다는 본 연구결과와 유사하다.

본 연구에서 영유아기 언어 및 어휘 평가에 대한 부모와 교사 간 상관관계 및 차이를 살펴본 결과, 영유아기 평가 시 부모뿐만 아니 라 교사 평가를 함께 고려할 필요가 있다는 점을 시사해 준다. 이는 언어발달지체 위험 영유아의 조기 선별 및 조기 중재에 대한 임상 적으로 유용한 정보를 제공해 줄 수 있다. 연구의 결과를 일반화하 기 위해 본 연구의 결론을 토대로 다음과 같이 제언한다. 본 연구는 일반 영유아 64 명의 부모와 교사 128 명만을 대상으로 연구하였다. 따라서 본 연구의 일반화를 위해서는 더 많은 영유아를 대상으로 
연구가 확장되어야 하며 연령대 범위를 좀 더 확장하고, 성별 차이 를 함께 고려한 후속 연구가 필요하다. 또한 본 연구에서는 영유아 건강검진에서 정상 소견을 받았다는 부모 보고에 근거해서 정상발 달 영유아만을 대상으로 하였으나 언어발달 위험군 또는 언어발달 지체 영유아에 대한 부모와 교사의 평가 결과를 비교함으로써 언 어발달장애 영유아의 조기 선별, 조기 중재의 임상적 통찰을 제공 해 줄 수 있을 것으로 사료된다.

\section{REFERENCES}

Beaty, J. J., \& Pratt, L. (2003). Early literacy in preschool and kindergarten. Ohio, USA: Merrill Prencite Hall.

Campbell, S. B. (2006). Behavior problems in preschool children: clinical and developmental issues (2nd ed.). New York, NY; Guilford Press.

Choi, E. (2000). A study of vocabulary development of Korean children (Master's thesis). Yonsei University, Seoul, Korea.

Clark, E. V. (1973). Non-linguistic strategies and the acquisition of word meanings. Cognition, 2(2), 161-182.

Dale, P. (1991). The validity of a parent report measure of vocabulary and syntax of 24 months. Journal of Speech and Hearing Research, 34(3), 565571.

Dale, P., Bates, E., Reznick, S., \& Morisset, C. (1989). The validity of a report instrument of child language at twenty months. Journal of Child Language, 16(2), 239-250.

Dickson, K. S., Suhrheinrich, J., Rieth, S. R., \& Stahmer, A. C. (2018). Parent and teacher concordance of child outcoms for youth with autism spectrum disorder. Journal of Autism and Developmental Disorders, 48(5), 1423-1435.

Efstratopoulou, M., Janssen, R., \& Simons, J. (2012). Agreement among physical education, teachers and parents on children's behaviors: a multitraitmultimethod design approach. Research in Developmental Disabilities, 33(5), 1343-1352.

Fenson, L., Dale, P., Reznick, S., Bates, E., Thal, D., Hartung, J., \& Reilly, J. (1993). Technical manual for the MacArthur communicative development. San Diego: San Diego State University.

Firmin, M. W., Proemmel, E., \& Hwang, C. (2005). A comparison of parent and teacher ratings of children's behaviors. Educational Research Quarterly, 29(2), 18-28.

Goldfield, B. A., \& Reznick, J. S. (1990). Early lexical acquisition: rate, content, and the vocabulary spurt. Journal of Child Language, 17(1), 171-184. Green, K., Beck, S., Forehand, R., \& Vosk, B. (1980). Validity of teacher nom- inations of child behavior problems. Journal of Abnormal Child Psychology, 8(3), 397-404.

Hoff, E. (2001). Language development (2nd). Stamford, CT: Wadsworth Thomson Learning.

Jang, Y. K. (2004). Early lexical development of Korean infants: 18-36 Months. The Korean Journal of Developmental Psychology, 17(4), 91-105.

Jeff, S., \& Donna, P. (1995). Parent and teacher assessment of receptive and expressive language in preschool children with developmental disabilities. Education and Training in Mental Retardation and Developmental Disabilities, 30(4), 329-335.

Joo, Y. H. (2010). Early childhood language development and education. Gyeonggido: Gyomoomsa.

Kang, H. K. (2011). Social supports and self-evaluation of school-aged children. Korean Journal of Parent Education, 8(1), 24-43.

Kim, H. K., Ahn, J. S., \& Kim, M. H. (2012). Agreement between parent and teacher reports in clinical setting: comparing SDQ-Kr with K-CBCL. Journal of the Korean Academy of Child and Adolescent Psychiatry, 23(3), 127133.

Kim, K. C., \& Kim, H. (2006). Comparison of mother-teacher's ratings on children's creativity. The Korea Open Association for Early Childhood Education, 11(3), 237-250.

Kim, Y. T. (2014). Assessment and treatment of language disorders in children. Seoul: Hakgisa.

Kim, Y. T., Kim, K. H., Yoon, H. R., \& Kim, H. S. (2003). Sequenced Language Scale for Infants (SELSI). Seoul: Special Education Publishing.

Knoors, H., Meuleman, J., \& Klatter-Folmer, J. (2003). Parents' and teacher' evaluations of the communicative abilities of deaf children. American Annals of the Deaf, 148(4), 287-294.

Lee, J. H. (1994). Perception and emotions of mothers of high-risk newborn infants. Journal of Korean Academy of Nursing, 24(4), 557-567.

Lee, J. H., Lee, S. M., \& Kim, J. W. (2013). Relationship between ADHD assessment by parents and teacher and family functioning. Journal of Emotional \& Behavioral Disorders, 29(1), 197-211.

Lee, S. Y., \& Choi, J. A. (2012). A comparison study of parent and teacher ratings on protective factors and behavioral concerns of young children from multicultural families. The Journal of Educational Studies, 43(3), 59-84.

Lee, Y., \& Lee, H. (2016). Development of intentional communicative behavior in Korean toddlers 12 to 30 months. Communication Sciences \& Disorders, 21(4), 553-566.

Mesman, J., \& Koot, H. M. (2000). Child-reported depression and anxiety in 
preadolescence: I. associations with parent- and teacher-reported problems. Journal of the American Academy of Child and Adolescence Psychiatry, 39(11), 1371-1478.

Merydith, S. P., Prout, H. T., \& Blaha, J. (2003). Social desirability and behavioral rating scale: an exploratory study with the Child Behavior Checklist/4-18. Psychology in the Schools, 40(2), 225-235.

Ministry of gender equality and family. (2007). Specific educational content and teacher guidelines for standard childcare courses. Seoul: Ministry of gender equality and family.

Pae, S., \& Kwak, K. C. (2011). Korean MacArthur-Bates communicative development inventories (KM-B CDI). Seoul: Mindpress.

Park, J., \& Lee, E. (2001). Development of a peer competence scale for preschool children. Family and Environment Research, 39(1), 221-232.

Park, W. K., Choi, S. K., \& Jeong, S. H. (2010). The difference in evaluations between teachers and parents on mental retardation`s adaptional behavior. Journal of Special Education: Theory and Practice, 11(3), 419-440.

Pua, E. P. K., Lee, M. L. C., \& Rickard Liow, S. J. (2017). Screening bilingual preschoolers for language difficulties: utility of teacher and parent reports. Journal of Speech, Language, and Hearing Research, 60(4), 950-968.

Robins, D. L., Fein, D., Barton, M. L., \& Green, J. A. (2001). The Modified Checklist for Autism in Toddlers: an initial study investigating the early detection of autism and pervasive developmental disorders. Journal of $A u$ tism and Developmental Disorders, 31(2), 131-144.

Ruchkin, V., Koposov, R., Vermeiren, R., \& Schwab-Stone, M. (2011). The Strength and Difficulties Questionnaire: Russian validationn of the teacher version and comparison of teacher and student reports. Journal of Adolescence, 35(1), 87-96.

Serna, L., Nielsen, E., Lambros, K., \& Forness, S. (2000). Primary prevention with children at risk for emotional or behavioral disorders: data on a universal intervention for Head Start classrooms. Behavioral Disorders, 26(1), 70-84.

Shin, C. S., \& Ahn, S. W. (2018). Comparison of the perception of parents, teachers, and speech-language pathologists on language ability of disabled children. The Journal of Special Education: Theory and Practice, 19(2), 187208.

Song, S. M., \& Kim, J. H. (2002). Agreement between parent's and teacher's ratings about problem behavior of the children with $\mathrm{ADHD}$ and Depression/Anxiety. The Korean Journal of Clinical Psychology, 21(4), 859-869.

Thal, D., O’Hanlon, L., Clemmons, M., \& Fralin, L. (1999). Validity of a parent report measure of vocabulary and syntax for preschool children with language impairment. Journal of Speech and Hearing Research, 42(2), 482496.

Tomblin, B., Shonrock, M., \& Hardy, C. (1989). The concurrent validity of the Minnesota Child Development Invent as a measure of young children's language development. Journal of Speech and Hearing Research, 54(1), 101105.

Wetherby, A. M., \& Prizant, B. M. (2002). Communication and symbolic behavior scales: developmental profile (1st normed ed.). Baltimore: Paul H. Brookes.

Wetherby, A., Warren, S., \& Reichle, J. (1998). Introduction to transitions in prelinguistic communication. In A. Wetherby, S. Warren, J. Reichle (Eds.), Transitions in prelinguistic, communication (pp. 1-11). Baltimore: Paul H. Hrookes Publishing.

Wetherby, A. M., Brosnan-Maddox, S., Peace, V., \& Newton, L. (2008). Validation of the Infant-Toddler Checklist as a broadband screener for autism spectrum disorders from 9 to 24 months of age. Autism, 12(5), 487-511. 


\section{국문초록}

\section{8-35개월 영유아의 언어발달에 대한 부모-교사 평가 비교}

\section{김윤희 · 정경희}

용인대학교 재활복지대학원 언어치료학과

배경 및 목적: 본 연구는 3 세 이전의 18-35개월 영유아의 언어발달 및 어휘발달 수준에 대한 부모와 보육교사의 평가 결과를 비교함으 로써 영유아 언어평가에 대한 임상적 정보를 제공하기 위한 목적으로 수행되었다. 방법: 연구의 대상은 총 64 명의 일반 영유아의 부모 와 교사로, 같은 아동에 대한 언어발달 수준 평가를 각각 실시하였다. 영유아의 언어능력 평가에 대한 부모와 교사 간 차이는 SELSI 전 체 점수, 수용언어 총점, 표현언어 총점으로, 어휘능력 평가는 K M-B CDI 전체 점수, 표현어휘 총점, 문법 총점으로 비교하였다. 결과: 첫째, SELSI 검사 결과 총점과 수용, 표현언어 점수 모두 부모와 교사 평가 점수 간 상관관계가 매우 높은 것으로 나타났다. 또한 18-23개 월, 24-29개월, 30-35개월 각 연령대별로도 매우 높은 상관관계가 나타났다. 둘째, SELSI 검사 결과, 총점 영역에서는 부모와 교사 평가 점수 간 차이가 유의하였으며, 교사가 다소 높은 점수로 평가한 것으로 나타났다. 하지만 수용언어와 표현언어 하위영역에서는 유의한 차이가 나타나지 않았다. 연령대에 따라 살펴보았을 때 30-35개월 영유아의 SELSI 총점에서만 부모와 교사 보고 간의 차이가 유의한 것 으로 나타났으나 다른 두 연령대에서는 모든 점수에서 유의한 차이가 나타나지 않았다. 셋째, $\mathrm{K} \mathrm{M-B} \mathrm{CDI} \mathrm{검사} \mathrm{결과} \mathrm{총점과} \mathrm{표현어휘,}$ 문법 점수 모두 부모와 교사 평가 간 상관관계가 매우 높은 것으로 나타났다. 또한 18-23개월, 24-29개월, 30-35개월 각 연령대 별로도 매우 높은 상관관계가 나타났다. 넷째, $\mathrm{KM}-\mathrm{B} \mathrm{CDI}$ 검사 결과 총점 및 표현어휘와 문법 하위영역에서도 유의한차이가 없었을 뿐 아니라 각 연령대별로도 모든 영역에서 유의한 차이가 나타나지 않았다. 논의 및 결론: 이 연구결과는 영유아기 평가 시 부모뿐 아니라 교사 평 가를 함께 고려할 필요가 있다는 점을 시사해 준다. 또한 이는 언어발달지체 위험 영유아의 조기 선별 및 조기 중재에 있어 임상적으로 유용한 정보를 제공해 줄수 있다.

핵심어: 영유아, 부모, 교사, 어휘, 언어발달

이 논문은 제 1 저자의 석사학위논문을 수정, 보완하였음.

\section{참고문헌}

강희경 (2011). 학령기 아동의 사회적 지지와 자기평가. 한국부모교육학회, 8(1), 25-43.

김경철, 김호 (2006). 유아의 창의성에 대한 어머니와 교사의 평정 비교. 열린유아교육연구, 11(3), 237-250.

김영태 (2014). 아동언어장애의 진단 및 치료. 서울: 학지사.

김영태, 김경희, 윤혜련, 김화수 (2003). 영유아 언어발달 검사(SELSI). 서울: 도서출판특수교육.

김홍규, 안정숙, 김민혁 (2012). 임상에서 부모-교사 보고의 일치: SDQ-Kr과 K-CBCL의 비교. 대한소아청소년정신의학회, 23(3), 127-133.

박원경, 최성규, 정승희 (2010). K-SIB-R을 활용한 정신지체아동의 적응행동에 대한 부모와 교사의 평가 차이. 특수교육저널: 이론과 실천, 11(3), 419-

440 .

박주희, 이은해 (2001). 취학 전 아동용 또래 유능성 척도 개발에 관한 연구. 대한가정학회지, 39(1), 221-232.

배소영, 곽금주 (2011). 한국판 맥아더-베이츠 의사소통 발달 평가(K M-B CDI). 서울: 마인드프레스.

송수미, 김재환 (2002). ADHD 및 우울/불안장애 아동의 문제행동에 대한 부모-교사간 평가 일치도. 한국심리학회지: 임상, 21(4), 859-869.

신창숙, 안성우 (2018). 장애유아의 언어능력에 대한 부모.교사.언어 재활사의 인식 비교. 특수교육 저널: 이론과 실천, 19(2), 187-208.

여성가족부 (2007). 표준보육과정의 구체적 교육내용 및 교사지침. 서울: 여성가족부.

이승연, 최정아 (2012). 다문화 가정 유아의 보호요인과 행동문제에 대한 부모와 교사의 평가 비교. 교육과학연구, 43(3), 59-84. 
이윤경, 이효주 (2016). 12-30개월 영유아의 의도적 의사소통 행동 발달. Communication Sciences \& Disorders, 21(4): 553-566.

이자형 (1994). 고위험 신생 아 어머니의 지각과 정서. 대한간호학회지, 24(4), 557-567.

이종하, 이상무, 김재원 (2013). ADHD에 대한 부모-교사간 평가와 가족기능에 관한 연구. 정서 - 행동장애연구, 29(1), 197-211.

장유경 (2004). 한국 영아 초기 어휘 발달: 18 개월-36개월. 한국심리학회지: 발달, 17(4) 91-105.

주영희 (2010). 유아언어발달과 교육. 경기도: 교문사.

최은희 (2000). 한국 아동의 어휘발달연구: 13-30개월 아동을 대상으로. 연세대학교 대학원 석사학위논문.

\section{ORCID}

김윤희(제1저자, 대학원생 https://orcid.org/0000-0002-2626-8449); 정경희(교신저자, 교수 https://orcid.org/0000-0002-1816-0171) 